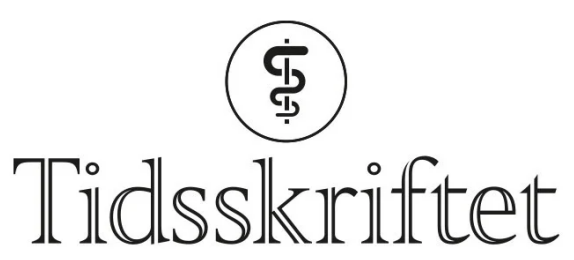

DEN NORSKE LEGEFORENING

\title{
T.M. Gundem og medarbeidere svarer
}

KOMMENTAR

TRINE MARIE GUNDEM

trimagu@online.no

Trine Marie Gundem er overlege ved Oslo universitetssykehus, Ullevål

THERESA MARIERO OLASVEENGEN

KNUT ERIK HOVDA

KNUT GAUSTAD

CHRISTINA SCHØNDORF

MORTEN ROSTRUP

STEN FRØYSHOV

ØYSTEIN UNDSETH

KRISTIAN TONBY

ALEKSANDER RYGH HOLTEN

KJETIL SUNDE

Ingen av forfatterne har oppgitt noen interessekonflikter.

Vi takker Laake og medforfattere for deres interesse, engasjement og tilbakemeldinger vedrørende våre nylig publiserte erfaringer med kritisk syke covid-19 pasienter innlagt på intensivavdelingen ved Oslo universitetssykehus, Ullevål. Vi er helt enige i at behandlingsvalg skal basere seg på internasjonale kunnskapsbaserte retningslinjer der dette foreligger. Vårt ønske med artikkelen var kun å beskrive og dele våre erfaringer med 
denne nye sykdommen, hvor vi fulgte intensivtrengende pasienter gjennom forskjellige faser av covid-19. I førsteutkastet av artikkelen inkluderte vi resultater fra pasientene som var ekskludert fra studien, men disse ble fjernet i henhold til tilbakemeldinger fra Tidsskriftet. Vi er enige i at disse pasientene også må medberegnes i helhetsbildet vedrørende behandling og utkomme.

Publisert: 7. september 2020. Tidsskr Nor Legeforen. DOI: 10.4045/tidsskr.20.0650

(C) Tidsskrift for Den norske legeforening 2023. Lastet ned fra tidsskriftet.no 26. april 2023. 